\title{
SOTEORIA UNTUK MISSIO DEI ANUGERAH KESELAMATAN UNTUK MISI ALLAH
}

\author{
Aeron F. Sihombing \\ PENDAHULUAN
}

\begin{abstract}
Banyak orang Kristen memiliki konsep maupun tindakan yang salah mengenai keselamatan atau soteria. Soteria yang mereka miliki dan cari hanyalah bersifat antroposentris, yang mementingkan diri sendiri atau berpusat kepada dirinya sendiri. Kecenderungannya adalah egois, yang mementingkan diri, pragmatis dan untuk kemuliaannya sendiri. Allah hanyalah sebagai pelengkap atau objek di dalam kehidupannya, yang mana Ia mencukupi dan memenuhi segala yang diingikannya melalui soteria atau keselamatan yang telah diberikanNya.
\end{abstract}

Soteria antroposentris ini bertentangan atau kontradiksi dengan soteria yang Allah inginkan, yaitu soteria untuk melakukan dan melaksanakan missio Dei atau misi Allah, semuanya adalah kemuliaan Allah atau soli deo glori. Dengan demikian, tulisan ini ingin merespons soteria antroposentris melalui kekristenan Injili menurut perspektif Reformed ${ }^{1}$ untuk memurnikan ajaran yang terdapat di dalam Gereja.

\section{ALASAN-ALASAN SOTERIA ANTROPOSENTRIS}

Beberapa alasan mengapa banyak orang Kristen memiliki konsep yang kurang tepat mengenai keselamatan yang mereka miliki:

\section{Soteria hanya untuk masuk surga}

Banyak orang Kristen pada saat ini hanya mempercayai bahwa mereka diselamatkan oleh Allah adalah hanya untuk masuk surga. Karena, tujuan kematian Kristus hanyalah memindahkan mereka dari neraka menuju surga. Mereka akan memperoleh kesenangan dan kebahagiaan di surga bersama-sama dengan orang-orang yang telah diselamatkan oleh Allah. Kristus mati hanya untuk dirinya sendiri dan demi kebahagiaannya. Dengan demikian, ia akan

${ }^{1}$ Anthony A. Hoekema, Diselamatkan oleh Anugerah (Surabaya: Momentum, 2001) 14. 
melupakan kehidupan yang ada di bumi dan ia hanya akan mementingkan kehidupan di surga. Ia hanya mementingkan hal-hal surgawi, tanpa mementingkan kehidupan di dunia ini. Ia akan memisahkan antara surga dan bumi, sehingga terjebak dalam dualisme.

\section{Kesembuhan dari penyakit ${ }^{2}$}

Ketika mendengar ada acara kebaktian kebangunan rohani yang dapat menyembuhkan segala penyakit dan akan ada mukjizat yang besar, maka banyak orang akan berbondong-bondong untuk menghadirinya. Ia mencari kesembuhan dari penyakit yang dideritanya bertahun-tahun, maupun ada juga yang ingin mukjizat besar yang akan terjadi. Ketika ada tantangan untuk percaya kepada Kristus, ia akan mau percaya kepada-Nya, sehingga ia akan disembuhkan dari penyakitnya.

Hal ini memang tidak salah, namun yang menjadi masalah adalah soteria atau keselamatannya hanyalah untuk kesembuhan dari penyakitnya. ${ }^{3}$ Hal ini sama seperti sepuluh orang yang penyakit kusta yang meminta kesembuhan dari Kristus (Lukas17:11-19), namun hanya satu orang yang datang kepadanya untuk berterima kasih dan mengucap syukur, ketika telah disembuhkan. Hal ini merupakan potret dari soteria antroposentris pada saat ini.

\section{Lepas dari segala masalah yang dihadapi}

Banyak masalah yang dihadapi manusia di dalam dunia ini. Dengan demikian, ia akan berusaha untuk lepas dari segala masalah dan tekanan hidup yang dihadapinya. ${ }^{4}$ Maka, orang-orang tersebut lari kepada Allah untuk memperoleh jawaban atas segala masalah yang dihadapinya.

Hal ini memang natural dihadapi oleh manusia. Untuk dapat lepas dari segala tekanan hidup tersebut, banyak orang mencarinya di dalam Kristus, sehingga mereka memperolehnya. Hal ini memang salah satu berkat yang

${ }^{2}$ Derek Prince, Atonement, Your Appointment With God (Grand Rapids: Chosen Books, 2000) 1-40.

${ }^{3}$ Ken Blue, Otoritas untuk Menyembubkan (Jakarta: Yayasan Pancar Pijar Alkitab, 2010) 82 .

4John Ortberg, If You Want to Walk on Water, You've Got to Get Out of the Boat (Michigan: Zondervan Publishing House, 2000)196-198. 
ditawarkan di dalam soteria, akan tetapi yang menjadi masalah adalah bahwa soteria yang dimilikinya hanyalah untuk melepaskannya dari segala tekanan, masalah hidup yang dihadapinya di dunia ini. Ia tidak mengetahui bahwa ada sesuatu rencana Allah dibalik semua itu.

\section{Ingin makmur atau kaya}

Kekayaan ataupun kemakmuran merupakan dambaan dari banyak orang, sehingga dicari dengan berbagai cara. Karena, ia ingin menikmati hidup dan ingin bahagia, dengan segala kekayaan yang dimilikinya. Oleh sebab itu, banyak orang datang kepada Allah untuk menikmati semuat itu. Teologi kesuksesan mengatakan bahwa orang yang telah percaya kepada Kristus akan memperoleh kemakmuran dan kekayaan. Hal inilah tujuan penebusan Kristus dan soteria yang telah diterimanya. ${ }^{5}$

Banyak orang percaya menganut ajaran ini, sehingga mereka berusaha untuk memberi persembahan yang melimpah kepada Allah dan juga beribadah kepada-Nya untuk memperoleh kekayaan ataupun kemakmuran. Hal ini merupakan suatu ajaran yang menyimpang dari kekristenan.

Masuk surga, kekayaan atau kemakmuran, sembuh dari penyakit, memperoleh atau mengalami mukjizat maupun dan lepas dari segala masalah yang dihadapi bukanlah sesuatu yang buruk atau salah. Karena, ini merupakan sesuatu yang layak untuk dimiliki oleh orang percaya yang telah menerima anugerah soteria atau keselamatan dari pada Allah. Namun, ia menjadi salah atau tidak benar adalah ketika konsep soteria atau keselamatannya adalah lebih bersifat antroposentis.

\section{PRINSIP-PRINSIP TERHADAP SOTERIA ANTROPOSENTRIS}

\section{Pragmatisme}

Banyak orang Kristen pada zaman sekarang yang berpikir pragmatis, yang terpenting adalah kegunaan atau manfaat dari sesuatu. Pragmatisme merupakan suatu nilai yang menghasilkan hasil-hasil yang berguna dan cocok bagi situasi-

\footnotetext{
5 Prince, Atonement ..., 1-40.
} 
situasi yang tertentu. ${ }^{6}$ Suatu nilai atau teori akan bermanfaat bila dipraktikkan atau dilakukan. Hal yang terpenting adalah hasil dan kegunaan di dalam kehidupan manusia. Dengan demikian, segala sesuatu yang bernilai adalah bila ada manfaatnya dirasakan oleh manusia dalam kehidupan.

Demikian juga di dalam kehidupan sehari-hari, ia tidak lagi berpikir dalam kerangka Teosentris, namun manfaat, kegunaan. Ia akan melakukan apa saja untuk keuntungan, bahkan sampai berkompromi dengan dunia ini. ${ }^{7}$ Misalnya, soteria yang diterimanya hanyalah untuk kepentingan pribadinya, yaitu untuk memperoleh kekayaan semata. Maka, dalam memberikan persembahan kepada Allah adalah berdasarkan prinsip give and take, apabila ia memberi persembahan kepada Allah satu juta, maka Allah akan mengembalikan seratus juta kepadanya, bahkan lebih dari pada itu.

\section{Humanistik}

Humanistik adalah manusia yang menjadi ukuran segala sesuatu. Dengan akalnya, ia akan memutuskan dan mengambil tindakan di dalam kehidupannya. Soteria yang dimilikinya hanyalah untuk kepuasannya, kesenangannya, kebahagiaannya. Jadi, soteria yang dimilikinya hanya berpusat kepada dirinya sendiri. Hal ini tidak benar, sebab soteria yang dimilikinya telah mengabaikan Allah.

\section{Eksistensialisme}

Ekses dari soteria antroposentris adalah eksistensialisme. Hal yang dipentingkan adalah kesenangan dan kepentingingan pribadinya, yaitu berjumpa dengan Allah di dalam soteria atau keselamatan yang telah diterimanya. Ia merasa bahwa masuk surga adalah satu-satunya yang dicari dan mengabaikan tujuan Allah dalam soteria yang dimilikinya. Ia hanya mementingkan surga dan melupakan bahwa ada tugas Allah baginya di dunia ini.

${ }^{6}$ Chales S. MacKenzie, "Positivisme, Eksistensialisme dan Pragmatisme," dalam Membangun WawasanDuniaKristen, (Ed), W.Andrew Hoffecker (Surabaya: Momentum, 2006).

Ibid, 311.

${ }^{7}$ Blamires, Pemikiran..., 10. 
Eksistensialis ini tidak salah di dalam kehidupan Kristen dan ini sangat penting, namun yang menjadi salah adalah eksistensialis antroposentis, karena ia bersifat egois dan hedonis. Hal yang penting adalah kesenangan pribadinya.

\section{DAMPAK DARI SOTERIA ANTROPOSENTRIS}

\section{Hedonisme rohani}

Orang Kristen yang memiliki soteria antroposentis merupakan orang Kristen yang hanya mencari kesenangan pribadinya sendiri. Ia mengginginkan soteria atau keselamatan dari Allah hanyalah untuk kesenangan dan kenikmatannya, seperti perjumpaannya dengan Allah, menikmati persekutuannya dengan Allah, sehingga ia mengalami sukacita, kebahagiaan, damai sejahtera. John Piper menyebut ini sebagai hedonisme rohani. ${ }^{8}$ Namun bagi Piper, istilah ini sebagai sesuatu yang positif bila di dalam Kristus. Tetapi, saya mengunakan istilah ini sebagai sesuatu yang negatif, bila ia memiliki konsep soteria antroposentris.

\section{Memperalat Allah}

Allah telah diperalaat oleh orang yang memiliki konsep soteria antroposentris, karena soteria atau keselamatan yang dimilikinya atau diterima hanyalah untuk dirinya sendiri. Ia ingin selamat, masuk surga, memperoleh kekayaan atau kemakmuran, kesembuhan demi keuntungannya, namun ia tidak mengindahkan Allah. Dengan demikian, Allah hanya dijadikan sebagai sumber berkat baginya, sama seperti jin Aladin, bila digosok-gosok maka ia akan keluar dari tempatnya. Lalu, ia akan mengabulkan segala semua yang dikehendakinya, sehingga Allah telah diperalat. ${ }^{9}$

\section{Egoisme}

Orang Kristen yang memiliki konsep soteria antroposentris adalah egois, karena ia hanya mengginginkan keselamatan demi dirinya, keuntungan, dan

${ }^{8}$ John Piper, Desiring God, Meditations of a Christian Hedonist (Portland: Multomah Press, 1996.

${ }^{9}$ Aeron F. Sihombing, "Respons Apologetis Terhadap Limited Godism yang Membatasi Persona Allah", dalam Te Deum-Jurnal Teologi dan Pengembangan Pelayanan Vol.,1., No.1 Juli-Desember (CIANJUR: STT SAPPI, 2011). 
kepuasannya sendiri. Ia tidak mengetahui dan menyadari bahwa soteria atau keselamatan adalah untuk melayani dan memuliakan Allah.

\section{Individualistis atau Subjektivisme}

Soteria antroposentris telah terjebak di dalam individualis atau subjektif, sehingga ia kecenderungannya adalah humanisme. Ia tidak memperdulikan Allah, apalagi orang lain di sekitarnya, khususnya Gereja. Oleh sebab itu, ia egois dan hedonis secara rohani, yang mana ia hanya ingin menikmati soteria atau keselamatan dari pada Allah. Dia lupa rancangan, maksud maupun tujuan Allah atas soteria yang diberikan.

\section{Materialistik}

Soteria antroposentris jatuh ke dalam sekularisme. Ini dapat terlihat dari tindakan orang Kristen yang kecenderungannya adalah materialistik. Ia hanya mencari hal-hal yang fisik, materi, yang mana dapat dirasakan hari ini dan sekarang. Hal ini terjadi untuk memuaskan nafsu manusia, sehingga ia bersifat konsumtif, maupun pragmatis.

\section{RESPONS INJILI}

Titik pijak atau berangkat dari soteria missio Dei adalah sola gracia dan sola fide yang merupakan untuk kemuliaan Allah atau soli deo glori. Jadi, soteria yang dianugerahkan Allah kepada orang percaya adalah untuk melakukan dan melaksanakan tujuan, maksud dan rencana Allah. Namun, semua ini hanyalah untuk kemuliaan Allah, bukan untuk kepentingan orang percaya semata. ${ }^{10}$

\section{Landasan atau Dasar Soteria Missio Dei}

\section{Allah Tritunggal sebagai fondasi dari Gereja}

Dasar dari pemikiran, dogma dan teologi Kristen, khususnya mengenai soteria solideo glori dalam misi adalah Allah, ${ }^{11}$ sehingga ini disebut dengan

${ }^{10}$ Louis Berkhof, Teologi Sistematika, Doktrin Keselamatan (Surabaya: Lembaga Reformed Injili Indonesia, 1977) 5-6.

${ }^{11}$ HeRomaan Bavink, Reformed Dogmatics, Prologomena, Vol.1.,(Grand Rapids: Baker Academics, 2003), 207. 
Teisme.Allah adalah realitas utama atau ultimate. ${ }^{12}$ Ia adalah yang mendasari dari segala sesuatu, karena segala sesuatu atau seluruh ciptaan berasal dari pada-Nya. 13 Semuanya bergantung pada-Nya, sebab ciptaan-Nya tidak kekal.

Allah Teisme Kristen ini adalah Tritunggal, yaitu Bapa, Anak dan Roh. ${ }^{14}$ Allah Tritunggal adalah yang memiliki tiga pribadi, tetapi satu hakikat yaitu keallahan-Nya. Tiga pribadi, yaitu Bapa, sebagai Allah secara umum, yang mana ditujukan sebagai Pencipta langit dan bumi; Anak, sebagai Yesus Kristus yang menyelamatkan manusia, di kayu salib; Oknum ketiga adalah Roh Kudus, sebagai yang bekerja menyadarkan orang dari dosa-dosa, melindungi, memelihara, maupun yang menuntun orang percaya kepada Allah dan yang menggerakkan orang percaya untuk melaksanakan ketetapan Allah yaitu missio Deiuntuk kemuliaan-Nya. ${ }^{15}$

\section{Allah Bapa menetapkan/memilih orang percaya}

Allah merancangkan dan menentukan segala sesuatu di dalam diri cuma-cuma atau opera ad intra. Apakah itu tentang penciptaan, penyelamatan atau soteria, predistinasi. Seorang pun tiada yang mengetahui apa yang terdapat di dalam opera ad intra Allah, karena keterbatasan manusia.

Allah di dalam opera ad intra telah merancangkan dan menentukan tentang keselamatan manusia yang telah jatuh di dalam dosa.Ini yang disebut dengan predistinasi, yang mana ini adalah kedaulatan Allah itu sendiri, yang tidak dapat diketahui dan dimengerti oleh akal manusia yang terbatas, sehingga menjadi suatu mistri bagi manusia. Manusia mengetahuinya di dalam opera ad extra atau dalam pekerjaan yang telah dilakukan Allah.Manusia mengetahuinya ketika telah melihat dan mengalami pekerjaan Allah di dalam dirinya maupun di dalam Alkitab yang telah dikanonkan.

12 Ronald H. Nash, Konflike Wawasan Dunia,Mengapa Memilih Wawasan Kekristenan di Tengab Berbagai Pemikiran Dunia, terj.Irwan Tjulianto (Surabaya: Momentum, 2000), 49.

13 Richard L. Pratt Jr., Menaklukkan Segala Pikiran Kepada Kristus, terj.Rahmiati Tanudjaja (Malang: SAAT, 1994)17.

${ }^{14}$ Cornelius Van Til, Christian Apologetics (Phillipsburg: Presbyterian and Reformed Publhishing Co., 1961) 8.

${ }^{15}$ Ibid, 257. 
Keselamatan atau soteria yang telah ditentukan oleh Allah bagi orang percaya atau Kristen di dalam kekekalan bukanlah hanya untuk menghindarkannya dari maut atau pun neraka, kekayaan atau kemakmuran, lepas dari semua masalah, memperoleh kesembuhan, mukjizat, maupun untuk kepentingan pribadi. Namun, Allah memanggilnya untuk melakukan suatu tugas yang mulia, yaitu untuk melayani-Nya di dunia ini dengan melakukan atau melaksanan missio Dei atau misi Allah yang telah diperintahkan-Nya di dalam Alkitab. Semuanya adalah untuk kemuliaan Allah dan bukan untuk kemuliaan semata dari manusia itu sendiri.

\section{Soteria dalam Kristus}

Tindakan Allah di dalam keselamatan atau soteria adalah di dalam Yesus Kristus yang telah mati di kayu salib.Di dalam Kristus, manusia berdosa menerima keselamatan atau soteria.Manusia tidak layak untuk mendapatkannya, namun Allah memberikannya secara cuma-cuma kepada manusia. Inilah anugerah yang sangat besar yang telah diterima oleh manusia yang berdosa.

Kristus mengatakan bahwa setiap orang yang percaya dan yang menerima soteria atau keselamatan daripada-Nya adalah bukan pilihan dari pada manusia itu sendiri, namun Allahlah yang telah memilih mereka untuk menerima soteria tersebut. Tujuannya adalah untuk bekerja dan melayani Allah, melalui missio Dei.

\section{Pekerjaan Roh Kudus melalui proses soteria dan missio Dei}

Roh Kudus yang bekerja di dalam proses penebusan. Ia mengubah manusia lama menjadi manusia yang baru di dalam Kristus atau yang bekerja di dalam proses lahir baru. Roh Kudus sebagai penjamin atau materai di dalam keselamatan dari orang percaya. Roh Kudus juga yang membimbing, mengarahkan, memelihara, menyertai Gereja di dalam panggilan dan pelayannya.Ia akan terus menegur dan mengingatkan Gereja di dalam dosa-dosa maupun di dalam panggilannya di dunia ini.

Secara khusus, Roh Kudus menggerakkan orang percaya di dalam melakukan missio Dei atau misi Allah. Ia akan terus bekerja di dalam diri orang percaya, agar melaksanakan dan menjalankan misi Allah terhadap dunia ini. Ia akan memberikan visi dan menuntun orang percaya untuk menggemban rencana Allah di dalam dunia ini. Hal inilah rancangan Allah di dalam opera ad intra untuk kemuliaan-Nya. 


\section{SOTEORIA DALAM/UNTUK MISSIO DEI}

\section{Melakukan Amanat Agung}

Di dalam opera ad intra, Allah menganugerahkan soteria atau keselamatan kepada orang percaya untuk melakukan dan melaksanakan tugas yang telah dirancangkan oleh-Nya. Tugas tersebut adalah amanat agung yang telah disampaikan melalui kitab suci, yaitu yang terdapat di dalam Matius 28:19-20, untuk pergi ke dunia, untuk menjadikan semua bangsa menjadi murid Kristus, serta membaptis mereka di dalam nama Tritunggal.

Maka, soteria atau keselamatan yang dianugerahkan kepada orang percaya bukanlah semata untuk memasukkan mereka ke dalam surga dan menikmati hidup yang penuh bahagia di sana, maupun untuk menikmati kehidupan yang nikmat di bumi. Ia harus melaksanakan amanat agung yang telah diberikan oleh Kristus. Ini merupakan suatu perintah kepada orang percaya, dan bukan sebagai suatu anjuran, yang dapat dilakukan maupun tidak dapat dilakukan olehnya. Amanat agung bukanlah pilihan orang percaya, namun suatu kewajiban, ketika ia telah menerima soteria.

\section{Menghadirkan Kerajaan Allah di Muka Bumi}

Misi Kristus datang ke dunia dan berinkarnasi adalah untuk membawa dan memberitakan kabar baik yaitu Kerajaan Allah (Matius4:17). Kerajaan Allah bukanlah suatu tempat atau wilayah seperti kerajaan politik seperti yang diharapkan oleh sebagian besar bangsa Yahudi pada zaman Kristus. Akan tetapi, Kerajaan Allah adalah suatu keadaan di mana Allah memerintah di dalam kehidupan orang yang telah menerima soteria. Kerajaan Allah tersebut adalah kelahiran, kematian, dan kebangkitan Kristus, yang mana sempurna ketika kedatangan-Nya yang kedua kali. ${ }^{16} \mathrm{Jadi}$, diri Kristus itu sendiri merupakan pusat maupun Kerajaan Allah tersebut.

Kerajaan Allah tersebut bersifat teosentris, yaitu berpusat kepada Allah dan bukan berpusat pada manusia atau antroposentris, karena ini merupakan suatu ketetapan atau rancangan Allah dari kekekalan. Allah menghadirkannya di dalam dunia melalui Kristus yang berinkarnasi; di dalam Kerajaan Allah tersebut ada

${ }^{16}$ Donald Guthrie, Teologi Perjanjian Baru 2, Misi Kristus, Rob Kudus, Kebidupan Kristen (Jakarta: BPK Gunung Mulia, 1998) 46. 
kuasa Allah yang besar, sehingga dapat menyelamatkan manusia dari kuasa maut maupun kegelapan; dan di dalamnya ada keselamatan atau soteria di dalam Kristus Yesus. ${ }^{17}$

Orang yang masuk ke dalam Kerajaan Allah tersebut adalah yang menerima soteria, yang telah diberikan Allah kepada manusia yang berdosa. Dengan demikian, ia akan menjadi warga Kerajaan Allah, yang mana Kristus memerintah di dalamnya. Oleh sebab itu, sebagai warga Kerajaan Allah, ia akan menjadi wakil dari Allah untuk menghadirkan Kerajaan Allah di bumi ini, melalui kehadirannya di tengah-tengah masyarakat, maupun dengan memberitakannya kepada dunia ini. Ini merupakan kehendak Allah yang telah ditetapkan bagi orang percaya yang telah menerima soteria. Maka, soteria yang dimiliki oleh orang percaya bukanlah untuk dirinya sendiri dan kepentingannya saja.

\section{Membawa Kedamaian}

Soteria yang telah diterima oleh orang percaya atau Kristen akan membawa kedamaian yang daripada Allah di dalam dirinya. Kedamaian abadi tersebut tidak hanya dinikmati oleh dirinya sendiri, akan tetapi ia harus membawa dan membagikannya kepada dunia maupun orang lain. Ini merupakan kewajiban dari orang percaya yang telah dibebankan Allah kepadanya.

Orang percaya bukanlah seseorang yang membawa kekacauan di dalam masyarakat, lingkungan, Gereja di mana ia berada. Namun, ia harus membawa kedamaian di tengah-tengah kekacauan dan tidak ada damai di mana ia berada. Dengan demikian, ia akan semakin berbahagia, karena ia telah membawa kedamaian yang ada di dalam dirinya kepada orang lain, masyarakat di sekitarnya, maupun kepada dunia ini.

Tuhan Yesus mengatakan di dalam Matius 5:9, "berbahagialah orang yang membawa damai, karena mereka akan disebut anak-anak Allah". Anak-anak Allah adalah status yang diberikan kepada manusia berdosa yang telah menerima soteria atau keselamatan daripada Allah, yang mana ia harus membawa damai kepada dunia ini. Hal ini merupakan bagiand dari missio Dei atau misi Allah yang diemban oleh orang percaya.

\section{Membawa Kebenaran dan Keadilan Sosial}

${ }^{17}$ Ibid., 32-34. 
Kehendak Allah memberikan keselamatan atau soteria kepada orang percaya adalah untuk membawa kebenaran dan keadilan sosial di muka bumi ini, atau di mana tinggal dan berada. Allah telah memilih dan memanggilnya untuk membawa kebenaran yang daripada Allah dan menegakkan keadilan sosial bagi masyarakat. Ini merupakan aspek atau bagian dari soteria yang diterimanya, sehingga ia tidak dapat hidup sendiri atau individualis untuk menikmati anugerah yang telah diterimanya.

Orang percaya harus membawa berita kebenaran dan menegakkan di tengah-tengah masyarakat yang telah jauh dari kebenaran dan juga menegakkan keadilan sosial bagi masyarakat atau orang-orang lemah, seperti orang miskin, orang yang tidak berdaya maupun orang-orang yang tidak mampu. Hal ini telah dilakukan oleh Kristus ketika di bumi, yang mana ia menegakkan kebenaran dan keadilan sosial. Ia membela dan membantu orang-orang yang miskin, tidak mampu dan lemah. Ia menyatakan kebenaran kepada orang-orang Yahudi, seperti ahli Taurat, Farisi dan pemerintah yang telah jauh dari kebenaran. Ia menyatakan apa yang salah dari pada bangsa Yahudi dan menyatakan dan menegakkan kebenaran.

Tugas yang diemban Kristus juga diteruskan oleh umat-Nya, kepada orangorang percaya yang telah menerima soteria, karena murid akan sama seperti gurunya. Inilah tugas kenabian yang diemban orang percaya di dalam panggilannya di tengah dunia ini. Jadi, seluruh hidupnya adalah untuk menjalankan ketetapan Allah. Landasannya adalah 1) Allah adalah Tuhan atas seluruh kehidupan orang percaya dan Allah wajib dimuliakan di dalam kehidupannya; 2) Tuhan bekerja dalam setiap bagian kehidupan orang percaya dan menuntuk peran serta orang percaya di dalam pekerjaan Allah di dalam dunia ini. ${ }^{18}$

\section{Bersaksi bagi Dunia}

Orang percaya adalah anak-anak Allah yang telah diadopsi melalui keselamatanatau soteria yang telah diberikan oleh Allah kepadanya. Maka, orang yang telah memperoleh keselamatan akan menjadi cermin dari Allah bagi dunia. Dunia akan mengenal dan mengetahui Allah melalui hidup dari orang percaya.

${ }^{18}$ Malcolm Brownlee, Tugas Manusia dalam Dunia Milik Tuban Jakarta: BPK Gunung Mulia, 2011) 22-23. 
Mereka akan mengetahuinya melalui tindakan dan perbuatan dalam kehidupan sehari-harinya.

Dengan demikian, orang percaya menjadi saksi Kristus di dunia ini. Ini adalah tugas orang percaya ketika Allah memanggilnya. Ini adalah kehendak Allah atas hidupnya. Ia harus menjadi garam dan terang di bumi ini. Seluruh kehidupannya menjadi saksi bagi Kristus, sehingga dunia akan melihat bahwa Allah adalah Allah segala bangsa dan Maha Kuasa. Kehadiran orang percaya akan menjadi mempengaruhi lingkungan di mana ia berada, meskipun jumlahnya hanya sedikit, sehingga akan mewarnai dunia, di mana ia berada. Hal ini merupakan bagian dari missio Deinya Allah di dalam keselamatan atau soteria yang diterima orang Kristen.

Jadi, orang percaya tidak dapat hanya menikmati keselamatan yang diterimanya, namun keselamatan yang diterimanya ditularkan kepada dunia, lingkungan sekitar di mana ia berada. Salah satunya adalah melalui kesaksian hidupnya, yang menjadi garam dan terang bagi dunia ini. Oleh sebab itu, orang percaya hidup bukan untuk dirinya sendiri, melainkan hidup bagi Allah dan dunia sekitarnya.

\section{Berapologetika bagi Gereja dan dunia}

Salah satu yang penting dari panggilan orang percaya adalah berapologetika bagi Gereja maupun bagi orang-orang yang telah meragukan kepercayaan iman Kristen. ${ }^{19}$ Maka, apologetika ${ }^{20}$ merupakan pertanggungjawaban iman Kristen

${ }^{19}$ Greg L. Bahnsen, Van Til's Apologetic, Reading and Analysis (Philipsburg: P\&R Publishing, 1998).

${ }^{20}$ Istilah apologetika berasal dari kata kerja Yunani apologeomai.apo, yang artinya kembali, sedangkan logeo (mai), berbicara atau berkata. Dengan demikian, arti secara literal adalah berbicara pada diri sendiri atau membela diri terhadap serangan dari luar atau orang yang mempertanyakan iman kekristenan (Roma2:15; Lukas21:14; Kisah Para Rasul26:1) (Togardo Siburian, Class Note: Apologetika Kristen (Bandung: STTB, 2011). Apologetika dilakukan secara sistematis, karena ia adalah suatu bidang ilmu yang dapat dipelajari. Dengan demikian, apologetika adalah suatu ilmu mengenai pertanggungjawaban iman Kristen secara sistematis logis di dalam menghadapi tantangan dari luar yang telah meragukan, menantang dan keberatan terhadap iman Kristen secara menyeluruh baik kehidupan dan wawasan atau pandangan dunia dari kekristenan (1Petrus3:15-16). Dari buku John M. Frame, Apologetika bagi Kemuliaan Allah, terj. R. Steve Hendra (Surabaya:Momentum, 2009) 3. Apologetika bukanlah untuk melakukan perdebatan atau penyerangan terhadap orang yang meragukan dan menyerang dan bukan juga untuk membela Allah.Akan tetapi, tugas dari apologetika 
(1Pet.3:15), terhadap orang-orang yang meragukan dan yang mempertanyakan iman Kristen. Ini merupakan tugas dari orang percaya untuk mempertanggungjawabkan imannya bila ia ditanya dan diserang oleh orang lain. Akan tetapi, apalogetika bukanlah untuk menyerang ajaran, agama, kepercayaan orang lain dan juga bukan debat kusir, sehingga kecenderungannya adalah untuk mencari musuh, namun hanya sebagai pertanggungjawaban Kristen, yang dilakukan dengan kasih.

Di samping itu, apologetika juga sekaligus untuk memberitakan iman Kristen kepada dunia, melalui pertanggungjawaban yang diberikannya. Hal ini dilakukan melalui afirmasi atau penegasan ulang akan iman atau kepercayaannya kepada orang yang meragukan dan menyerang iman Kristen.

Apologetika sebagai penjaga kebenaran.Salah satu tugas dari gereja adalah menjaga kebenaran ${ }^{21}$ dari serangan-serangan dari luar, maupun dari dalam gereja itu sendiri, khususnya yaitu ajaran-ajaran yang telah menyimpang dari kekristenan.Ada serangan dari dalam Gereja, yaitu khususnya daripada bidat, maupun dari dunia yang meragukan iman Kristen. Hal ini bukan berarti Allah perlu dibela oleh orang percaya, sebab Allah tidak perlu dibela oleh manusia yang terbatas, sebab Allah adalah maha kuasa, pencipta langit dan bumi. Namun, apolegetika dilakukan hanya sebagai bentuk dari pertanggungjawaban iman kepada dunia, melalui penegasan atau afirmasi dari iman maupun kepercayaannya.

\section{Penegasan ulang Soteria untuk MISSIO DEI}

\section{Soteria berpusat pada Allah/teosentris}

Soteria atau keselamatan yang dianugerahkan Allah kepada orang percaya adalah berpusat kepada Allah. Ia bukan untuk kepentingan diri sendiri, atau berpusat pada manusia. Ia bukanlah bersifat humanis, demi keuntungan dan kemuliaan manusia itu sendiri. Sebab, kehendak dan tujuan Allah dalam

bertugas untuk mengkomunikasikan kepercayaan atau iman Kristen terhadap orang yang telah meragukan, keberatan maupun yang menantang dari kekristenan.

${ }^{21}$ Louis Berkhof, Reformed Dogmatics Vol.II (Grand Rapids: W.M.B. Eerdmands Publishing Co., 1932), 161. 
memberikan keselamatan bagi orang percaya adalah untuk menjalankan misi Allah atas dunia.

Allah mengginginkan bagi orang percaya untuk melakukan kehendak-Nya di muka bumi ini, yaitu sebagai melakukan amanat agung seperti memuridkan, memberitakan Injil, membabtis; menghadirkan Kerajaan Allah; menjadi saksi, menyatakan keadilan dan kebenaran di muka bumi ini. Hal ini dilakukan melalui misi yang Allah kehendaki di dalam panggilan maupun pilihan-Nya atas orang percaya.

\section{Soteoria untuk Solideo Glori}

Soteria yang dimiliki oleh orang percaya bukanlah sebatas hanya untuk memiliki karcis untuk masuk surga, untuk memperoleh kekayaan atau kemakmuran, kesehatan, kebahagiaan dan juga bukan untuk hanya untuk kemuliaan manusia itu sendiri. Namun, keselamatan atau soteria yang dianugerahkan Allah adalah untuk kemuliaan-Nya atau soli Deo glori. Allah menganugerahkan keselamatan kepada orang percaya, agar ia melakukan kehendak, rancangan-Nya di muka manapun ia berada. Allah ingin agar orang yang belum percaya mengetahui dan mengenal Allah, melalui missio Dei yang dilakukan atau dilaksanakan oleh orang percaya.

Maka, orang percaya menjadi alat Allah dan wakil Allah di dunia ini. Hal ini dilaksanakan oleh orang percaya bukan untuk kemuliaan maupun kehormatannya sendiri. Namun, semua ini adalah untuk memuliakan Allah di dalam kehidupan orang percaya. Jadi, semuanya adalah hanyalah untuk kemuliaan Allah, Soli Deo Glori.

\section{Orang yang menerima soteria sebagai Agen Allah di muka bumi}

Orang percaya diselamatkan Allah yaitu sebagai agen atau wakil-Nya di dunia ini. Ungkapan ini sama seperti yang dikatakan oleh William Barclay sebagai duta Kristus di bumi ini. Dengan demikian, keselamatan atau soteria yang dimilikinya adalah untuk bekerja bagi Kristus. Ia sebagai wakil Allah untuk melakukan mandat atau misi Allah di manapun ia berada.

Hal ini juga merupakan bagian dari anugerah yang diterima oleh orang percaya untuk melakukan kehendak Allah. Karena, orang percaya dipakai dan dipercaya oleh Allah untuk bekerja bagi-Nya. Ia adalah manusia yang berdosa dan tidak layak, namun Allah memberikan kepercayaan dan melayakkannya 
sebagai alat untuk menggenapkan rancangan dan kehendak-Nya di muka bumi ini.

\section{KESIMPULAN}

Keselamatan atau soteria yang diterima oleh orang percaya bukanlah hanya sekadar untuk kepentingan dirinya sendiri, hanya berpusat kepada manusia itu sendiri atau antroposentris. Misalnya adalah keselamatan hanyalah untuk masuk surga, menikmati hidup di surga, memperoleh kekayaan, kenikmatan dan kebahagiaan di dunia, hedonisme rohani, memperoleh kesehatan, lepas dari masalah maupun untuk kemuliaan dirinya sendiri. Dengan demikian, ia akan memperalat Allah. Ini memang tidak salah, namun menjadi salah ketika bersifat antroposentris yang memuliakan diri sendiri, dan mengabaikan Allah.

Allah di dalam opera ad intra-Nya di dalam kekekalan untuk memberikan keselamatan atau soteria kepada orang percaya adalah untuk kemuliaan-Nya, yaitu untuk melakukan missio Dei atau misi Allah di dunia ini, yaitu seperti melakukan amanat agung, menjadi saksi di manapun ia berada, menghadirkan Kerajaan Allah di manapun ia berada, membawa kedamaian, membawa keadilan dan kebenaran.

Dengan demikian, manusia harus bekerja dan melayani Allah untuk menggenapkan rencana dan tujuan Allah di dunia ini. Hal inilah mengapa Allah memberikan anugerah keselamatan atau soteria kepada orang percaya, yaitu untuk melakukan maupun melaksanakan missio Dei atau misi Allah di muka bumi ini. Semuanya adalah untuk kemuliaan Allah atau soli Deo glori. Jadi, keselamatan atau soteria yang dianugerahkah Allah kepada orang percaya adalah untuk soli Deo glori yang dilakukan melalui missio Dei.

\footnotetext{
AERON FRIOR SIHOMBING mendapatkan gelar S.Th dari STT INTI, Bandung dan M.Div. dari STTB Bandung. Sekarang mengajar sebagai dosen tetap di STT SAPPI.
} 